\title{
Assessment of Different Saccharification and Fermentation Configurations for Ethanol Production from Agave lechuguilla
}

Thelma K. Morales-Martínez, ${ }^{a}$ Deniss I. Díaz-Blanco, ${ }^{a}$ José A. Rodríguez-de la Garza, ${ }^{a}$ Jesús Morlett-Chávez, ${ }^{\mathrm{b}}$ Agustín J. Castro-Montoya, ${ }^{\mathrm{c}}$ Julián Quintero, ${ }^{\mathrm{d}}$ Germán Aroca, ${ }^{\mathrm{d}}$ and Leopoldo J. Rios-González ${ }^{\mathrm{a}, *}$

\begin{abstract}
Different strategies were assessed for the production of ethanol from Agave lechuguilla that was pretreated by autohydrolysis. Separate hydrolysis and fermentation (SHF) was compared against simultaneous processes including simultaneous saccharification and fermentation (SSF) and prehydrolysis and simultaneous saccharification and fermentation (PSSF) using different solids $(15 \%, 20 \%$, and $25 \% \mathrm{w} / \mathrm{w}$ ) and enzyme loadings (15 FPU/g, $20 \mathrm{FPU} / \mathrm{g}$, and 25 FPU/g glucan). The results showed that the maximum ethanol concentration $(53.7 \mathrm{~g} / \mathrm{L})$ and productivity $\left(1.49 \mathrm{~g} / \mathrm{L} \mathrm{h}^{-1}\right)$ was obtained at $36 \mathrm{~h}$ in the SHF configuration at the highest solids and enzyme loadings $(25 \% \mathrm{w} / \mathrm{v}$ and 25 FPU/g glucan, respectively). The ethanol concentration and productivity obtained in the PSSF configuration at the same time were $45 \mathrm{~g} / \mathrm{L}$ and $1.25 \mathrm{~g} / \mathrm{L}$ $\mathrm{h}^{-1}$, respectively. The SSF configuration exhibited the lowest ethanol concentration and productivity $\left(10.4 \mathrm{~g} / \mathrm{L}\right.$ and $0.29 \mathrm{~g} / \mathrm{L} \mathrm{h}^{-1}$, respectively) at $36 \mathrm{~h}$. The enzyme used, Cellic CTec3, allowed for high glucose yields at the lower enzyme dosage assessed. The SHF configuration exhibited the best results. However, the PSSF configuration can be considered an attractive alternative because it eliminated the need for solid-liquid separation devices, which simplifies the industrial implementation of the process.
\end{abstract}

Keywords: Agave lechuguilla; Autohydrolysis; Different process configuration; Ethanol

Contact information: a: Departamento de Biotecnología, Facultad de Ciencias Químicas, Universidad Autónoma de Coahuila, Saltillo, Coahuila México; b: Laboratorio de Biología Molecular, Facultad de Ciencias Químicas, Universidad Autónoma de Coahuila, Saltillo, Coahuila México; c: Facultad de Ingeniería Química, Universidad Michoacana de San Nicolás de Hidalgo, Morelia, Michoacán, México; d: Escuela de Ingeniería Bioquímica, Pontificia Universidad Católica de Valparaíso, Chile;

*Corresponding author: leopoldo.rios@uadec.edu.mx

\section{INTRODUCTION}

Agave lechuguilla is a common plant found in northern Mexico and occupies the largest range of all agaves with almost 20 million hectares of the arid and semiarid lands of Mexico (Castillo et al. 2013). The species has traditionally been exploited for fiber extraction (Pando-Moreno et al. 2008) and has recently been reported as a feedstock for ethanol production (Ortíz-Méndez et al. 2017). Agave lechuguilla cogollos (heart or pulpy central stem with attached leaf bases) can be harvested several times without sacrificing the whole plant. The annual productivity is 4 tons per hectare, with an average rainfall of 427 mm (Escamilla-Treviño 2012).

The production of ethanol from lignocellulosics can be performed by three major steps, including the pretreatment of the raw material, hydrolysis of cellulose, and biological conversion of sugars to ethanol (Triwahyuni et al. 2015). The hydrolysis of cellulose can 
be achieved via an acid or enzymatic process. However, enzymatic hydrolysis presents diverse advantages compared to acid hydrolysis because it requires less energy, mainly because the process is carried out at lower temperatures (approximately $50{ }^{\circ} \mathrm{C}$ for enzymatic hydrolysis $v s$. over $150^{\circ} \mathrm{C}$ for acid hydrolysis), it does not produce inhibitory by-products, and it is an environmentally friendly process (López-Linares et al. 2014). However, it has been suggested that to make the lignocellulose conversion process more economically feasible, the enzymatic hydrolysis process must be carried out using high solids loadings. Theoretically, high concentrations of sugars will result in a higher ethanol production, which could reduce energy use and costs associated with the distillation process (Modenbach and Nokes 2013). Nevertheless, increasing the solids concentration in enzymatic hydrolysis leads to decreased yields, particularly due to the initial high viscosity of fibrous materials, resulting in poor mixing and impaired enzyme performance (Sant'Ana da Silva et al. 2016).

The hydrolysis and fermentation process can be achieved by several strategies, including separate hydrolysis and fermentation (SHF), simultaneous saccharification and fermentation (SSF), and prehydrolysis and simultaneous saccharification and fermentation (PSSF) (Paulova et al. 2015). To the knowledge of the authors, few reports on ethanol production from agave hydrolysates are available, and those that exist are mainly focused on the use of the SHF configuration with yeast (Hernández-Salas et al. 2009; SaucedoLuna et al. 2011; Caspeta et al. 2014; Corbin et al. 2015; Mielenz et al. 2015; RiosGonzález et al. 2017) or on the SSF configuration with ethanologenic bacteria (PérezPimienta et al. 2017).

The integration of two or more process steps is important for simplifying the process and reducing the production cost (Wang et al. 2013; Narra et al. 2015). The SHF configuration is performed in two separate steps: first the enzymatic hydrolysis of pretreated cellulose and then the fermentation of sugars to ethanol; and each step can be carried out at its optimal process condition (de Barros et al. 2017). In the SSF configuration, the enzyme and microbe are synergically performing. This configuration is also advantageous because both processes happen in a single step. However, enzymatic hydrolysis has a low performance because the optimal temperature for yeasts is lower than that for enzymatic hydrolysis (Neves et al. 2016). In the PSSF configuration, the pretreated material is prehydrolyzed at the optimal temperature of the enzyme complex and the temperature is then lowered for further inoculation with no other additional step. The main advantage of PSSF over SHF is that it simplifies the process by eliminating the need to separate the slurry before fermentation. Regarding the advantage of the PSSF configuration compared to the SSF configuration, the rate of enzymatic hydrolysis is not reduced by the suboptimal temperature and the ethanol production rate is not limited by the low concentration of carbon source (Paulova et al. 2015).

The aim of this work is to assess and compare the SHF, SSF, and PSSF configurations at different solids and enzyme loadings for ethanol production from $A$. lechuguilla biomass pretreated by autohydrolysis.

\section{EXPERIMENTAL}

\section{Materials}

Agave lechuguilla cogollos were collected from the municipality of Ramos Arizpe, Coahuila, Mexico. The cogollos were dried in a tray dehydrator (model KL10, Koleff S.A. 
de C.V., Queretaro, Mexico) at $45{ }^{\circ} \mathrm{C}$ until the moisture content was less than $10 \%$ of the total weight. Subsequently, the dried cogollos were milled and sieved in a Retsch SM100 cutting mill (Retsch SM100, Retsch, Haan, Germany) to 2-mm particle size prior to compositional analysis and autohydrolysis pretreatment. The material was mixed to obtain a homogeneous sample and stored at room temperature in hermetic containers.

\section{Feedstock composition and autohydrolysis pretreatment}

The moisture content was determined with a moisture analyzer (Moisture Analyzer OHAUS, Ohaus Co., Parsippany, NJ, USA). The extractives and ash content were determined using the National Renewable Energy Laboratory (NREL) analytical methods NREL/TP-510-42619 (Sluiter et al. 2005) and NREL/TP-510-42622 (Sluiter et al. 2008), respectively. The Laboratory Analytical Procedure (LAP) from the NREL (NREL/TP-51042618) was modified for the determination of cellulose (glucan), hemicellulose (xylan), and lignin according to Mussatto et al. (2011). The material $(500 \mathrm{mg})$ was hydrolyzed with $72 \%(\mathrm{w} / \mathrm{w})$ sulfuric acid $\left(\mathrm{H}_{2} \mathrm{SO}_{4}\right)$ for $7 \mathrm{~min}$ at $50{ }^{\circ} \mathrm{C}$. The obtained hydrolysate was subsequently diluted to $4 \%$ (w/w) $\mathrm{H}_{2} \mathrm{SO}_{4}$ by adding distilled water. A second hydrolysis was performed by autoclaving the reaction mixture at $121{ }^{\circ} \mathrm{C}$ for $1 \mathrm{~h}$. The autoclaved solution filtered through $0.2-\mu \mathrm{m}$ filters for High Performance Liquid Chromatography (HPLC) analysis, and the solid residues that remained after filtration were used to determine the acid insoluble lignin (Klason lignin). The proteins were determined by the Kjeldahl method (Ortíz-Méndez et al. 2017).

Autohydrolysis pretreatment of A. lechuguilla was performed in a 5-gallon highpressure stainless steel reactor (Parr Instruments Co., Moline, IL, USA). The dried and milled material (2.192 $\mathrm{kg}$ of A. lechuguilla) was suspended in $13.15 \mathrm{~L}$ of distilled water (resulting in a 1:6 w/v solid/liquid ratio) at $190{ }^{\circ} \mathrm{C}, 200 \mathrm{rpm}$ for $30 \mathrm{~min}$; these conditions were established previously by Ortíz-Méndez et al. (2017).

The reactor was rapidly cooled down once the reaction time was reached. The pretreated material was then separated by filtration. The liquid fraction was analyzed by HPLC, injecting a $20 \mu \mathrm{L}$ sample to determine the concentration of glucose, xylose, other sugars (mannose, arabinose, and galactose), and a $10 \mu \mathrm{L}$ sample to determine inhibitors, such as, formic acid, acetic acid, furfural, and hydroxymethylfurfural (HMF). The solid fraction was washed with water (30 times the volume of the material) and stored at $4{ }^{\circ} \mathrm{C}$ until further use in the SHF, SSF, and PSSF experiments. The glucan, xylan, and lignin in the solid fraction were determined as described above.

\section{Enzyme}

Cellic ${ }^{\circledR}$ CTec3 was kindly provided by Novozymes ${ }^{\circledR}$ (Kalundborg, Denmark). The cellulase activity (with a value of 217) of the enzyme complex was determined as described by Ghose (1987) in Filter Paper Units per mL (FPU/mL).

\section{Inoculum and medium}

Saccharomyces cerevisiae ATCC 4126 was used for the ethanol production. The inoculum was grown in 125-mL Erlenmeyer flasks with $50 \mathrm{~mL}$ of the following medium: yeast extract $(10 \mathrm{~g} / \mathrm{L})$, monopotassium phosphate $(1.17 \mathrm{~g} / \mathrm{L})$, calcium chloride $(0.09 \mathrm{~g} / \mathrm{L})$, magnesium sulfate $(0.36 \mathrm{~g} / \mathrm{L})$, and ammonium sulphate $(4.14 \mathrm{~g} / \mathrm{L})$. The medium was supplemented with $15 \mathrm{~mL} / \mathrm{L}$ of a salts solution containing: sodium chloride $(1.26 \mathrm{~g} / \mathrm{L})$, cupric sulfate $(0.26 \mathrm{~g} / \mathrm{L})$, ferrous sulphate $(0.22 \mathrm{~g} / \mathrm{L})$, manganese chloride $(0.12 \mathrm{~g} / \mathrm{L})$, zinc chloride $(0.32 \mathrm{~g} / \mathrm{L})$, and glucose $(100 \mathrm{~g} / \mathrm{L})$. The $\mathrm{pH}$ medium was adjusted to 5.5 with $2 \mathrm{M}$ 
$\mathrm{NaOH}$ before inoculation. The flasks were incubated in an orbital shaker (New Brunswick $^{\mathrm{TM}}$ 124/24R, New Brunswick Scientific Co., Inc., Hauppauge, NY, USA) at 100 $\mathrm{rpm}$ and $35^{\circ} \mathrm{C}$ for $24 \mathrm{~h}$. Five $\mathrm{g} / \mathrm{L}$ of cells $(10 \% \mathrm{v} / \mathrm{v})$ were used as inoculum in all of the experiments.

\section{Methods}

Process configurations- SHF

The enzymatic hydrolysis was conducted in 125-mL Erlenmeyer flasks using different enzyme (15 FPU/g, 20 FPU/g, and 25 FPU/g glucan) and solids loadings (15\%, $20 \%$, and $25 \% \mathrm{w} / \mathrm{w}$ dry matter) in a sodium citrate buffer at $0.05 \mathrm{M}(\mathrm{pH} 4.8)$. The solids loading was $15 \%(\mathrm{w} / \mathrm{w})$ for experiments 1,2 , and 3, $20 \%(\mathrm{w} / \mathrm{w})$ for experiments 4,5 , and 6 , and $25 \%(\mathrm{w} / \mathrm{w})$ for experiments 7, 8, and 9. Each solids loading was assessed at 15 FPU/g, $20 \mathrm{FPU} / \mathrm{g}$, and $25 \mathrm{FPU} / \mathrm{g}$ glucan. The experiments were conducted in an orbital shaker at $50{ }^{\circ} \mathrm{C}$ and $200 \mathrm{rpm}$ for $24 \mathrm{~h}$. At the end of the hydrolysis reaction, the glucose concentration was measured by HPLC.

The hydrolysates were centrifuged at 5,500 rpm for $15 \mathrm{~min}$ in a Thermo Scientific centrifuge (Haraeus ${ }^{\mathrm{TM}}$ Megafuge $^{\mathrm{TM}} 16 \mathrm{R}$, Rockford IL, USA). The supernatants were fermented $(10 \% \mathrm{v} / \mathrm{v}$ inoculum) in a $125-\mathrm{mL}$ Erlenmeyer flask with $15 \mathrm{~mL}$ of hydrolysates (supplemented with the nutrients described above; $\mathrm{pH}$ 5.5) and were incubated in an orbital shaker at $35^{\circ} \mathrm{C}$ and $150 \mathrm{rpm}$ for $24 \mathrm{~h}$. Samples were taken at $6 \mathrm{~h}, 12 \mathrm{~h}, 18 \mathrm{~h}$, and $24 \mathrm{~h}$ for ethanol and glucose quantification by HPLC.

The enzymatic hydrolysis yield was expressed as the relationship between the amount of glucose released during saccharification and the initial amount of glucan present in the pretreated material. The ethanol yield was reported as a percentage of the theoretical yield assuming all the potential glucose present can be fermented, with a maximum theoretical ethanol yield of $0.51 \mathrm{~g}$ ethanol/g glucose.

$S S F$

The SSF assays were conducted in $125-\mathrm{mL}$ Erlenmeyer flasks at the same conditions described for the SHF configuration. The SSF assays were performed for $72 \mathrm{~h}$ at $35{ }^{\circ} \mathrm{C}$, adding simultaneously the enzyme and the inoculum $(10 \% \mathrm{v} / \mathrm{v})$ at the beginning of the process. Samples were taken at 12 h, 24 h, 48 h, and $72 \mathrm{~h}$ and centrifuged at 5,500 rpm for 15 min in a micro-centrifuge (Heraeus ${ }^{\mathrm{TM}}$ Biofuge ${ }^{\circledR}$ Pico, Thermo Fisher Scientific, Waltham, MA, USA) for ethanol and glucose quantification by HPLC.

\section{Prehydrolysis and simultaneous saccharification and fermentation (PSSF)}

The pre-hydrolysis was performed under the same conditions described for the SHF configuration for $24 \mathrm{~h}$; after this time and without separating the slurry from the flasks, the temperature was readjusted to $35^{\circ} \mathrm{C}$, inoculated $(10 \% \mathrm{v} / \mathrm{v})$, and incubated in an orbital shaker at $150 \mathrm{rpm}$ for $72 \mathrm{~h}$. The samples were removed and centrifuged for analysis at 12 h, $24 \mathrm{~h}, 36 \mathrm{~h}, 48 \mathrm{~h}, 72 \mathrm{~h}$, and $96 \mathrm{~h}$ to determine the ethanol and glucose concentrations by HPLC.

\section{Analytical methods}

The glucose, xylose, galactose, arabinose, mannose, formic acid, acetic acid, and ethanol were determined by a HPLC unit (Agilent 1260 Infinity, Santa Clara, CA, USA) equipped with a refractive index detector at $45^{\circ} \mathrm{C}$, using an Agilent Hi-Plex H column at $35^{\circ} \mathrm{C}(7.7 \times 300 \mathrm{~mm}$, Santa Clara, CA, USA $)$ and $5 \mathrm{mM} \mathrm{H}_{2} \mathrm{SO}_{4}$ as the mobile phase at a 
flow rate of $0.5 \mathrm{~mL} / \mathrm{min}$. Furfural and hydroxymethylfurfural (HMF) were measured using the same equipment and column (at $55^{\circ} \mathrm{C}$ ) described above using a UV detector at $220 \mathrm{~nm}$ with a mixture of $5 \mathrm{mM} \mathrm{H}_{2} \mathrm{SO}_{4}$ and acetonitrile at a ratio of 9:1 as the eluent and a flow rate of $0.4 \mathrm{~mL} / \mathrm{min}$. The cellular growth of the inoculum was determined by correlating the optical density of cells using a UV/vis spectrometer (Varian, Palo Alto, CA, USA) at 660 $\mathrm{nm}$ with the dry weight. All experiments were performed in triplicate and the average values are reported. An analysis of variance (ANOVA) was conducted along with Fisher's F test with a $p$ value of $<0.05$ (Minitab ${ }^{\circledR}$ version 17, Minitab Inc., State College, PA, USA).

\section{RESULTS AND DISCUSSION}

\section{Composition of $\boldsymbol{A}$. lechuguilla and Autohydrolysis Pretreatment}

The composition of A. lechuguilla cogollos on a dry basis was: extractives $37 \%$, glucan $22.2 \%$, xylan $7.86 \%$, lignin $18.3 \%$, ash $7 \%$, protein $5.5 \%$, and other non-quantified compounds $2.14 \%$. The composition of A. lechuguilla pretreated by autohydrolysis is summarized in Table 1. The recovered sample after treatment was enriched in glucan and the total polymerized sugar content was higher compared to the untreated biomass (increasing from $22.2 \%$ to $41.0 \%$ ). From the initial glucan content present in the untreated material, $71 \%$ remained in the solid fraction. Autohydrolysis pretreatment mainly affected the hemicellulosic components, and under these conditions $92 \%$ of the original xylan content was solubilized. This is in agreement with the results of Amiri and Karimi (2015) and Zhuang et al. (2016), who reported that most of the xylan was hydrolyzed during pretreatment while the glucan and insoluble lignin were retained in the solid fraction. The solid recovered from pretreatment was $39.5 \%$ of the original raw material; this loss was attributed to the removal of extractives and xylan during the process. The lignin was not significantly solubilized during the pretreatment.

Table 1. Composition of Solid and Liquid Fractions after Autohydrolysis Pretreatment of $A$. lechuguilla

\begin{tabular}{|c|c|c|c|}
\hline \multicolumn{2}{|c|}{ Pretreated Solids (\% w/w) } & \multirow{2}{*}{\multicolumn{2}{|c|}{$\frac{\text { Liquid Fraction }(\mathrm{g} / \mathrm{L})}{\text { Suqars }}$}} \\
\hline Solids recovery & $39.50 \pm 2.12$ & & \\
\hline & & Glucose & $0.26 \pm 0.04$ \\
\hline \multirow[t]{2}{*}{ Glucan } & $40.98 \pm 1.16$ & Xylose & $6.43 \pm 0.19$ \\
\hline & & Other sugars ${ }^{a}$ & ND \\
\hline \multirow[t]{2}{*}{ Xylan } & $1.52 \pm 0.47$ & \multicolumn{2}{|c|}{ Inhibitors } \\
\hline & & Acetic acid & $4.66 \pm 0.09$ \\
\hline Lignin & $44.25 \pm 0.71$ & Formic acid & $1.95 \pm 0.03$ \\
\hline & & Furfural & $0.84 \pm 0.05$ \\
\hline Ash & $2.94 \pm 0.48$ & HMF & $0.57 \pm 0.01$ \\
\hline
\end{tabular}

During pretreatment, the main byproducts were acetic acid, formic acid, furfural, and HMF with concentrations in $\mathrm{g} / \mathrm{L}$ of $4.66,1.95,0.84$, and 0.57 , respectively. The acetic acid formation during the pretreatment process promotes the xylan dissolution as a result of the $\mathrm{pH}$ decrease. This behavior was previously described by Rios-González et al. (2017) using agave bagasse pretreated by autohydrolysis; the authors reported an acetic acid concentration in the range of $5.33 \mathrm{~g} / \mathrm{L}$ to $10 \mathrm{~g} / \mathrm{L}$ at $190{ }^{\circ} \mathrm{C}$ with operation times ranging from $15 \mathrm{~min}$ to $60 \mathrm{~min}$. 


\section{Process Configurations Assessment}

Table 2 shows the effect of solids and enzyme loading on final glucose concentration and hydrolysis yield. It can be observed that in the three configurations (SHF, SSF, and PSSF) assessed, the glucose concentration increased as the solids loading increased within the experiments performed with a maximum of $108.8 \mathrm{~g} / \mathrm{L}, 66.9 \mathrm{~g} / \mathrm{L}$, and $107.2 \mathrm{~g} / \mathrm{L}$ for SHF, SSF, and PSSF, respectively, under the same conditions (solids and enzyme loadings of $25 \%$ and $25 \mathrm{FPU} / \mathrm{g}$ glucan, respectively). In the case of the SSF configuration, the glucose concentration decreased 38\% and 37\% (experiment 9) when compared with the SHF and PSSF configurations, respectively.

In spite of the glucose concentration increment, when increasing the solids loading, the hydrolysis yield in the cases of the SHF and PSSF configurations decreased (Table 2). As reported by López-Linares et al. (2014), using acid pretreated rapeseed straw in a SHF configuration, the glucose concentration increased roughly linearly with the increase of solids loading; however the hydrolysis yield diminished. It has been suggested (LópezLinares et al. 2014) that this phenomenon is caused by diffusional limitations in the medium containing a high proportion of solids rather than to a loss of enzymatic activity due to end-product inhibition. Xue et al. (2012) mentioned that high enzyme loadings can improve enzymatic hydrolysis yield at high solids loading. However, in this work, the enzyme complex Cellic ${ }^{\circledR}$ CTec 3 showed that a smaller enzyme loading of $15 \mathrm{FPU} / \mathrm{g}$ glucan can be used to obtain similar hydrolysis yield (maximum difference of $7.4 \%$ ) compared with the maximum enzyme loading assessed of $25 \mathrm{FPU} / \mathrm{g}$ glucan.

The increase in enzyme loading from $15 \mathrm{FPU} / \mathrm{g}$ to $20 \mathrm{FPU} / \mathrm{g}$ of glucan and 20 FPU/g to $25 \mathrm{FPU} / \mathrm{g}$ of glucan increased the hydrolysis yield between $1 \%$ to $4.4 \%$, regardless of the solids loading; it is therefore not recommended to increase the enzyme loading because it will not result in a noticeably higher hydrolysis yield. According to Olofsson et al. (2008), an increase of 50\% in enzyme loading should be justified if an increase in the hydrolysis yield is greater than $6 \%$. Therefore, the enzyme loading can be optimized to provide the maximum glucose concentration at the lowest unit cost (Wang et al. 2012).

Table 2. Glucose Released and Hydrolysis Yield in Different Configurations (SHF, SSF, and PSSF) at $24 \mathrm{~h}$ of Enzymatic Hydrolysis

\begin{tabular}{|c|c|c|c|c|c|c|c|c|}
\hline \multirow{3}{*}{$\begin{array}{l}\text { Exp. } \\
\text { No. }\end{array}$} & \multicolumn{5}{|c|}{ Final Glucose (g/L) } & \multicolumn{3}{|c|}{$\begin{array}{c}\text { Hydrolysis Yield } \\
(\%)^{c}\end{array}$} \\
\hline & \multicolumn{8}{|c|}{ Process Configurations } \\
\hline & $S L^{a}$ & $E L^{b}$ & SHF & SSF & PSSF & SHF & SSF & PSSF \\
\hline 1 & & 15 & $65.0 \pm 0.14$ & $22.1 \pm 1.27$ & $63.7 \pm 0.52$ & 96.1 & 32.6 & 94.2 \\
\hline 2 & & 20 & $66.3 \pm 0.57$ & $23.7 \pm 1.32$ & $65.5 \pm 0.47$ & 98.0 & 35.0 & 96.8 \\
\hline 3 & & 25 & $67.0 \pm 0.34$ & $25.2 \pm 1.19$ & $66.3 \pm 0.38$ & 99.0 & 37.2 & 98.0 \\
\hline 4 & & 15 & $81.9 \pm 0.82$ & $42.0 \pm 1.41$ & $82.2 \pm 1.06$ & 90.8 & 46.5 & 91.2 \\
\hline 5 & & 20 & $84.5 \pm 0.67$ & $44.5 \pm 0.71$ & $84.7 \pm 0.75$ & 93.7 & 49.3 & 94.0 \\
\hline 6 & & 25 & $87.9 \pm 1.34$ & $47.0 \pm 1.13$ & $88.7 \pm 1.21$ & 97.5 & 52.1 & 98.4 \\
\hline 7 & & 15 & $101.1 \pm 0.57$ & $58.5 \pm 0.99$ & $100.5 \pm 0.71$ & 89.7 & 51.9 & 89.1 \\
\hline 8 & & 20 & $105.5 \pm 0.71$ & $62.0 \pm 1.7$ & $104.5 \pm 0.7$ & 93.6 & 55.0 & 92.7 \\
\hline 9 & & 25 & $108.8 \pm 0.49$ & $66.9 \pm 1.55$ & $107.2 \pm 0.35$ & 96.5 & 59.3 & 95.1 \\
\hline
\end{tabular}

Morales-Martínez et al. (2017). "Ethanol production," BioResources 12(4), 8093-8105. 
The highest hydrolysis yield (99\%) was obtained in the SHF configuration at $15 \%$ solids loading and $25 \mathrm{FPU} / \mathrm{g}$ glucan enzyme loading. A similar hydrolysis yield (98.4\%) was obtained in the PSSF configuration using 20\% solids loading and 25 FPU/g glucan enzyme loading. In contrast, glucan conversion in the SSF configuration was lower (59.4\%; the highest value for this configuration) compared to the SHF and PSSF configurations at $25 \%$ solids loadings and $25 \mathrm{FPU} / \mathrm{g}$ glucan enzyme loading. The hydrolysis yields obtained in the SSF configuration were not considered an absolute magnitude, but rather an apparent magnitude because the glucose released from the cellulose in the enzymatic reaction was consumed by yeasts during the fermentation process. In addition, the optimal temperature in SSF was different for saccharification and fermentation. Paulová et al. (2014) reported a plunge in the hydrolysis yield due to discrepancies in the optimal temperatures for both processes. In the present study, when using a temperature of $50{ }^{\circ} \mathrm{C}$ in the SSF configuration, no ethanol production was detected at $72 \mathrm{~h}$ (data not shown).

The maximum ethanol concentration was obtained when using the hydrolysate with the highest glucose concentration: $53.7 \mathrm{~g} / \mathrm{L}$ in SHF, $25.9 \mathrm{~g} / \mathrm{L}$ in SSF, and $50.3 \mathrm{~g} / \mathrm{L}$ in PSSF, which corresponded to ethanol yields of $96.8 \%, 75.9 \%$, and $91.9 \%$, respectively (Table 3 ). The lowest ethanol concentration obtained in the SSF configuration was attributed to the low glucose concentration. Long exposure at non-optimum temperatures contributes to enzyme deactivation (Kristensen et al. 2009), which was confirmed by the low glucose concentration in the media available for ethanol production.

Table 3. Ethanol Concentration, Hydrolysis, and Ethanol Yield in Different Configurations: SHF (at $24 \mathrm{~h}$ fermentation), SSF (at $72 \mathrm{~h}$ fermentation), and PSSF (at $24 \mathrm{~h}$ fermentation)

\begin{tabular}{|c|c|c|c|c|c|c|c|c|}
\hline \multirow{3}{*}{$\begin{array}{l}\text { Exp. } \\
\text { No. }\end{array}$} & \multicolumn{5}{|c|}{ Final Ethanol (g/L) } & \multicolumn{3}{|c|}{$\begin{array}{c}\text { Ethanol Yield } \\
\left(\mathbf{g}_{\text {ethanol }} / \mathbf{g}_{\text {glucose }}\right)-(\%)^{c}\end{array}$} \\
\hline & \multicolumn{8}{|c|}{ Process Configurations } \\
\hline & $S L^{a}$ & $E L^{b}$ & SHF & SSF & PSSF & SHF & SSF & PSSF \\
\hline 1 & & 15 & $31.7 \pm 0.42$ & $8.5 \pm 0.64$ & $31.2 \pm 0.54$ & $\begin{array}{c}0.49 \\
(95.7)\end{array}$ & $\begin{array}{c}0.39 \\
(75.8)\end{array}$ & $\begin{array}{c}0.49 \\
(96.1)\end{array}$ \\
\hline 2 & & 20 & $32.0 \pm 0.57$ & $9.2 \pm 0.31$ & $31.7 \pm 0.99$ & $\begin{array}{c}0.48 \\
(94.6)\end{array}$ & $\begin{array}{c}0.39 \\
(76.5)\end{array}$ & $\begin{array}{c}0.48 \\
(94.9)\end{array}$ \\
\hline 3 & & 25 & $32.6 \pm 0.21$ & $9.5 \pm 0.64$ & $32.1 \pm 0.92$ & $\begin{array}{c}0.49 \\
(95.5)\end{array}$ & $\begin{array}{c}0.38 \\
(74.3)\end{array}$ & $\begin{array}{c}0.48 \\
(95.0)\end{array}$ \\
\hline 4 & & 15 & $40.4 \pm 0.68$ & $16.7 \pm 0.28$ & $39.2 \pm 0.81$ & $\begin{array}{c}0.49 \\
(96.7)\end{array}$ & $\begin{array}{c}0.40 \\
(77.9)\end{array}$ & $\begin{array}{c}0.48 \\
(93.5)\end{array}$ \\
\hline 5 & & 20 & $41.2 \pm 0.39$ & $17.3 \pm 0.49$ & $40.5 \pm 0.77$ & $\begin{array}{c}0.49 \\
(95.7)\end{array}$ & $\begin{array}{c}0.39 \\
(76.4)\end{array}$ & $\begin{array}{c}0.48 \\
(93.7)\end{array}$ \\
\hline 6 & & 25 & $43.7 \pm 1.18$ & $18.0 \pm 0.71$ & $42.7 \pm 0.3$ & $\begin{array}{c}0.50 \\
(97.5)\end{array}$ & $\begin{array}{c}0.38 \\
(75.0)\end{array}$ & $\begin{array}{c}0.48 \\
(94.4)\end{array}$ \\
\hline 7 & & 15 & $49.2 \pm 0.35$ & $22.9 \pm 1.28$ & $46.2 \pm 0.35$ & $\begin{array}{c}0.49 \\
(95.5)\end{array}$ & $\begin{array}{c}0.39 \\
(76.7)\end{array}$ & $\begin{array}{c}0.46 \\
(90.2)\end{array}$ \\
\hline 8 & & 20 & $50.6 \pm 0.92$ & $23.7 \pm 1.13$ & $48.5 \pm 0.71$ & $\begin{array}{c}0.48 \\
(94.1)\end{array}$ & $\begin{array}{c}0.38 \\
(75.1)\end{array}$ & $\begin{array}{c}0.46 \\
(91.0)\end{array}$ \\
\hline 9 & & 25 & $53.7 \pm 0.35$ & $25.9 \pm 1.34$ & $50.3 \pm 0.42$ & $\begin{array}{c}0.49 \\
(96.8)\end{array}$ & $\begin{array}{c}0.39 \\
(75.9)\end{array}$ & $\begin{array}{c}0.47 \\
(91.9)\end{array}$ \\
\hline
\end{tabular}

Comparing the three process configurations, the ethanol concentrations were higher in the SHF and PSSF configurations, which was attributed to the better fermentation 
performance in the separate process, because in the SSF configuration the difference between the optimal temperatures of both processes (hydrolysis and fermentation) affected the cellulose hydrolysis rate and caused carbon limitation in fermentation at lower temperatures. In contrast, it could affect the activity of cellulolytic enzymes, thus slowing down the metabolism of the microbial strain at higher temperatures. Both approaches resulted in a reduction of productivity and a lower or non-existent ethanol production.

Figure 1 shows the glucose consumption and the ethanol production kinetics during the fermentation stage in the SHF configuration at different solids loadings $(15 \%, 20 \%$, and $25 \%$ and $25 \mathrm{FPU} / \mathrm{g}$ glucan). The glucose was consumed before $10 \mathrm{~h}$ with solids loadings of $15 \%$ and $20 \%$. However, at a $25 \%$ solids loading, total glucose consumption occurred at $12 \mathrm{~h}$. The maximum ethanol production obtained was $53.7 \mathrm{~g} / \mathrm{L}$ in experiments conducted with a $25 \%$ solids loading and $24 \mathrm{~h}$ of incubation (without noticeable increase after $12 \mathrm{~h}$ ). Other studies reported ethanol production using different agave species residues as feedstock, such as Hernández-Salas et al. (2009), Saucedo-Luna et al. (2011), Caspeta et al. (2014), and Rios-González et al. (2017), in which final ethanol concentrations of 6.6 $\mathrm{g} / \mathrm{L}, 24.68 \mathrm{~g} / \mathrm{L}, 64 \mathrm{~g} / \mathrm{L}$, and $65.2 \mathrm{~g} / \mathrm{L}$, respectively, were reported when pretreating with $\mathrm{NaOH}$, diluted $\mathrm{H}_{2} \mathrm{SO}_{4}$, organosolv and ionic liquid, and autohydrolysis, respectively. The difference in ethanol production was attributed to the cellulose content of the agave species and type of pretreatment method.

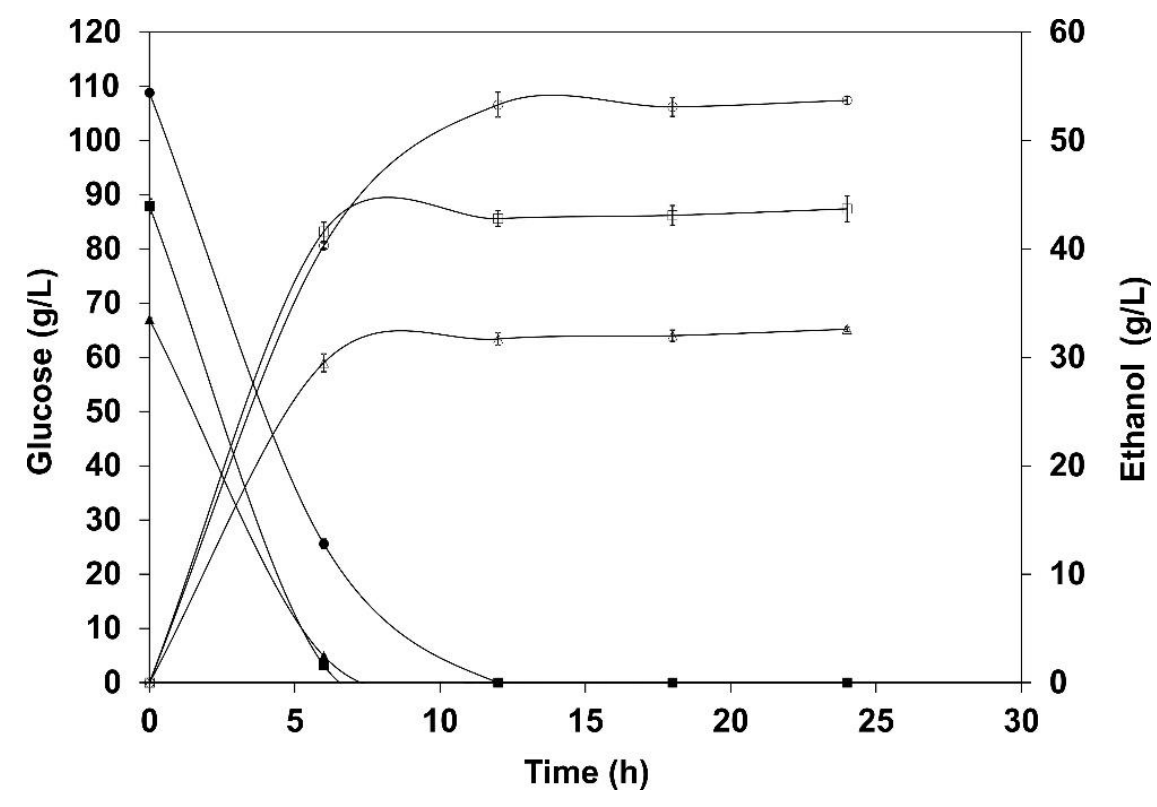

Fig. 1. Kinetics of glucose consumption (filled markers) and ethanol production (unfilled markers) during the fermentation stage of the SHF configuration at different solids loadings (w/w): $15 \%$ $(\mathbf{\Delta}), 20 \%(\square)$, and $25 \%(\bullet)$, and $25 \mathrm{FPU} / \mathrm{g}$ glucan

Figure 2 shows the kinetics of the SSF configuration at different solids loadings and $25 \mathrm{FPU} / \mathrm{g}$ glucan. The ethanol concentrations obtained at $72 \mathrm{~h}$ were $9.5 \mathrm{~g} / \mathrm{L}, 18 \mathrm{~g} / \mathrm{L}$, and $25.9 \mathrm{~g} / \mathrm{L}$ at $15 \%, 20 \%$, and $25 \%$ of solids loading, respectively. The results indicated that increased solids loading led to higher glucose concentrations, reaching the maximum glucose concentrations after $24 \mathrm{~h}$ for the different solids loading assessed. Glucose was not detected in the simultaneous process at $72 \mathrm{~h}$ for the solids loadings assessed. A $12 \mathrm{~h}$ lag was observed in the ethanol production, which can be attributed to yeast adaptation and 
propagation as reported by Neves et al. (2016). The SSF configuration usually achieves an ethanol yield in the range of $60 \%$ to $85 \%$ according to different reports, regardless of the feedstock, enzyme complex, or pretreatment method used (García-Aparicio et al. 2011; López-Linares et al. 2014; Pérez-Pimienta et al. 2017). The results obtained in the present study were in agreement with the aforementioned reports.

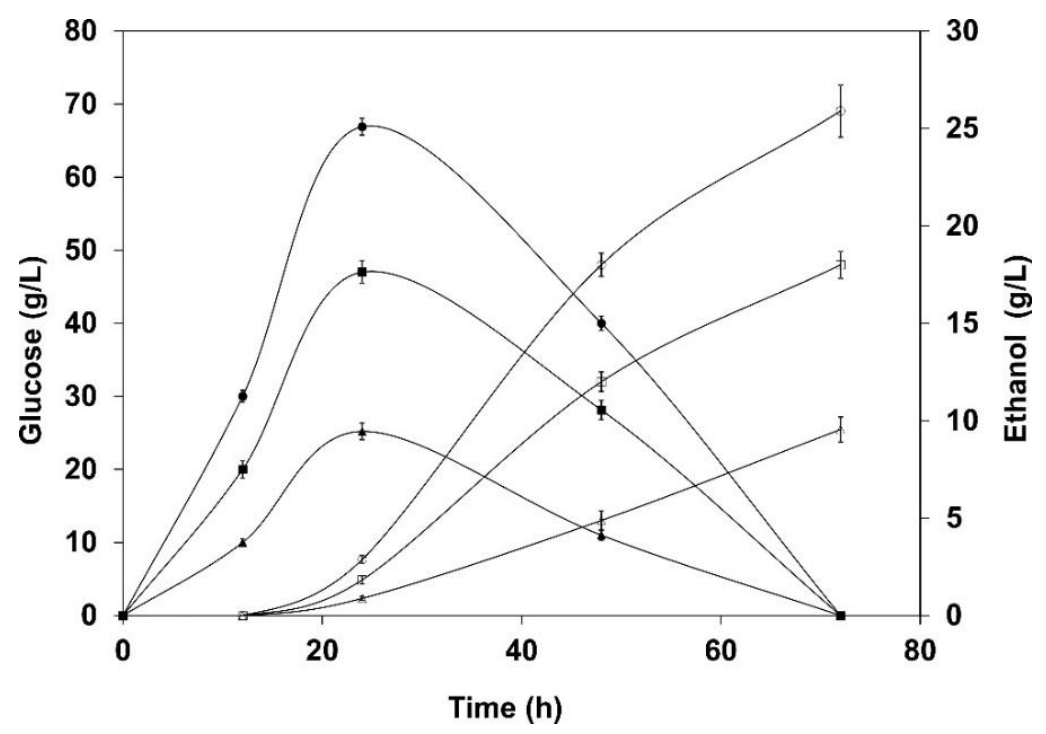

Fig. 2. Kinetics of glucose production and consumption (filled markers) and ethanol production (unfilled markers) in the SSF configuration at different solids loadings (w/w): $15 \%(\boldsymbol{\Delta}), 20 \%(\boldsymbol{\square})$, and $25 \%(\bullet)$, and $25 \mathrm{FPU} / \mathrm{g}$ glucan

To assess the PSSF configuration, a prehydrolysis was performed after $24 \mathrm{~h}$, followed by the SSF operation at $15 \%, 20 \%$, and $25 \%$ solids loadings and $25 \mathrm{FPU} / \mathrm{g}$ glucan. Figure 3 shows that after $24 \mathrm{~h}$ of prehydrolysis, the maximum glucose concentrations were $66.3 \mathrm{~g} / \mathrm{L}, 88.7 \mathrm{~g} / \mathrm{L}$, and $107.2 \mathrm{~g} / \mathrm{L}$ at $15 \%, 20 \%$, and $25 \%$ solids loadings, respectively.

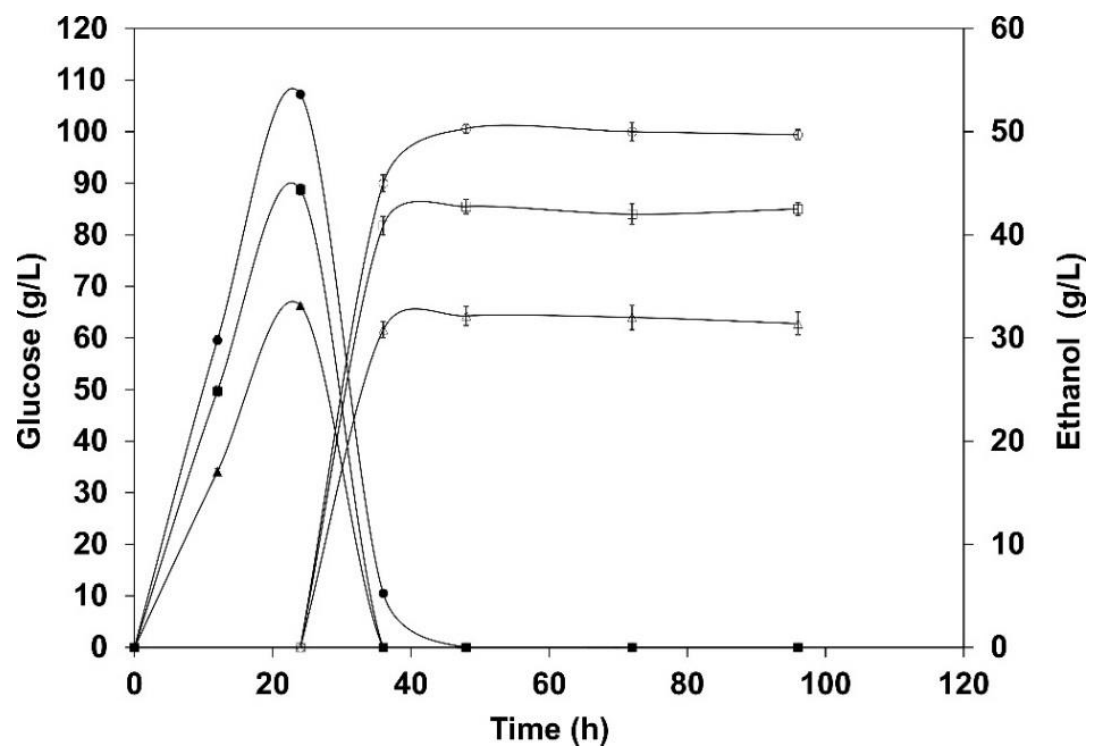

Fig. 3. Kinetics of glucose production and consumption (filled markers) and ethanol production (unfilled markers) in the PSSF configuration at different solids loadings (w/w): $15 \%(\boldsymbol{\Delta}), 20 \%(\boldsymbol{\square})$, and $25 \%,(\bullet)$ and $25 \mathrm{FPU} / \mathrm{g}$ glucan 
It was observed in all experiments that after inoculation, the glucose was rapidly consumed and the ethanol concentration increased, which achieved the highest ethanol concentrations of $32.1 \mathrm{~g} / \mathrm{L}, 42.7 \mathrm{~g} / \mathrm{L}$, and $50.3 \mathrm{~g} / \mathrm{L}$ at $15 \%, 20 \%$, and $25 \%$ solids loadings, respectively. No additional increment in ethanol concentration was detected after $24 \mathrm{~h}$. However, the maximum ethanol production and total glucose consumption after inoculation was achieved after more time when compared to the SHF configuration. This can be attributed to the fact that yeast was subjected to stress conditions due to high solids loading (López-Linares et al. 2014).

\section{CONCLUSIONS}

1. Comparing the SHF and PSSF configurations, the ethanol concentrations and productivity achieved at $36 \mathrm{~h}$ (saccharification plus fermentation time) were $53.7 \mathrm{~g} / \mathrm{L}$ and $1.49 \mathrm{~g} / \mathrm{L} \mathrm{h}^{-1}$ and $45 \mathrm{~g} / \mathrm{L}$ and $1.25 \mathrm{~g} / \mathrm{L} \mathrm{h}^{-1}$, respectively.

2. In contrast, the SSF configuration exhibited the lowest achieved ethanol concentration and productivity at the same time $\left(10.4 \mathrm{~g} / \mathrm{L}\right.$ and $0.29 \mathrm{~g} / \mathrm{L} \mathrm{h}^{-1}$, respectively).

3. The results obtained in the present work show that the SHF configuration can be considered the best alternative using the Cellic ${ }^{\circledR} \mathrm{CTec} 3$ enzyme complex.

4. This enzyme complex allowed for a high hydrolysis yield with the lower enzyme dosage assessed in this study (15 FPU/g glucan).

5. A lower enzyme requirement is a relevant factor for operation cost reduction when scaling-up the ethanol production process for A. lechuguilla. The PSSF configuration can be an attractive alternative if the initial investment and reduction in the number of required stages of the process are taken into account.

\section{ACKNOWLEDGMENTS}

The authors are grateful to the Secretariat of Agriculture, Livestock, Rural Development, Fisheries and Food of Mexico (SAGARPA) Grant No. 175404, to the National Council of Research and Technology (CONACyT) through the Bioenergy Thematic Network ("Red Mexicana de Bioenergía"), Grant No. 260457, and to the International Cooperation Programs CONACyT/CONICyT Grant No. PCCI140053, 2014.

\section{REFERENCES CITED}

Amiri, H., and Karimi, K. (2015). "Autohydrolysis: A promising pretreatment for the improvement of acetone, butanol, and ethanol production from woody materials," Chemical Engineering Science 137(1), 722-729. DOI: 10.1016/j.ces.2015.07.020

Caspeta, L., Caro-Bermudez, M. A., Ponce-Noyola, T., and Martinez, A. (2014). "Enzymatic hydrolysis at high-solids loadings for the conversion of agave bagasse to fuel ethanol," Applied Energy 113(1), 277-286. DOI: 10.1016/j.apenergy.2013.07.036 
Castillo, Q. D., Sáenz, R. J. T., Narcia, V. M., and Vázquez, R. J. A. (2013). "Physical and mechanical properties of Agave lechuguilla Torr. fiber under plantations of five provenances," Revista Mexicana de Ciencias Forestales 4(19), 78-91.

Corbin, K. R., Byrt, C. S., Bauer, S., Debolt, S., Chambers, D., Holtum, J. A. M., Karem, G., Henderson, M., Lahnstein, J., Beahan, C. T., Bacic, A., Fincher, G. B., Betts, N. S., and Burton, R. A. (2015). "Prospecting for energy-rich renewable raw materials: Agave leaf case study," PLoS One 10(8), 1-23. DOI: 10.1371/journal.pone.0135382

de Barros, E. M., Carvalho, V. M., Rodrigues, T. H. S., Rocha, M. V. P., and Gonçalves, L. R. B. (2017). "Comparison of strategies for the simultaneous saccharification and fermentation of cashew apple bagasse using a thermotolerant Kluyveromyces marxianus to enhance cellulosic ethanol production," Chemical Engineering Journal 307(1), 939-947. DOI: 10.1016/j.cej.2016.09.006

Escamilla-Treviño, L. L. (2012). "Potential of plants from the genus agave as bioenergy crops," Bioenergy Research 5(1), 1-9. DOI: 10.1007/s12155-011-9159-x

García-Aparicio, M. P., Oliva, J. M., Manzanares, P., Ballesteros, M., Ballesteros, I., and Gonzalez, A. (2011). "Second-generation ethanol production from steam exploded barley straw by Kluyveromyces marxianus CECT 10875,” Fuel 90(4), 1624-1630. DOI: 10.1016/j.fuel.2010.10.052

Ghose, T. K. (1987). "Measurement of cellulase activities," Pure and Applied Chemistry 59(2), 257-268. DOI: 10.1351/pac198759020257

Hernández-Salas, J. M., Villa-Ramírez, M. S., Veloz-Rendón, J. S., Rivera-Hernández, K. N., González-César, R. A., Plascencia-Espinosa, M. A., and Trejo-Estrada, S. R. (2009). "Comparative hydrolysis and fermentation of sugarcane and agave bagasse," Bioresource Technology 100(3), 1238-1245. DOI: 10.1016/j.biortech.2006.09.062

Kristensen, J. B., Felby, C., and Jørgensen, H. (2009). "Yield-determining factors in high-solids enzymatic hydrolysis of lignocellulose," Biotechnology for Biofuels 2(11), 1-10. DOI: 10.1186/1754-6834-2-11

López-Linares, J. C., Romero, I., Cara, C., Ruiz, E., Moya, M., and Castro, E. (2014). "Bioethanol production from rapeseed straw at high solids loading with different process configurations," Fuel 122(1), 112-118. DOI: 10.1016/j.fuel.2014.01.024

Mielenz, J. R., Rodriguez, M., Thompson, O. A., Yang, X., and Yin, H. (2015). "Development of agave as a dedicated biomass source: Production of biofuels from whole plants," Biotechnology for Biofuels 8(79), 1-13. DOI: 10.1186/s13068-0150261-8

Modenbach, A. A., and Nokes, S. E. (2013). "Enzymatic hydrolysis of biomass at highsolids loadings - A review," Biomass and Bioenergy 56(1), 526-544. DOI: 10.1016/j.biombioe.2013.05.031

Mussatto, S. I., Carneiro, L. M., Silva, J. P. A., Roberto, I. C., and Teixeira, J. A. (2011). "A study on chemical constituents and sugars extraction from spent coffee grounds," Carbohydrate Polymers 83(2), 368-374. DOI: 10.1016/j.carbpol.2010.07.063

Narra, M., James, J. P., and Balasubramanian, V. (2015). "Simultaneous saccharification and fermentation of delignified lignocellulosic biomass at high solid loadings by a newly isolated thermotolerant Kluyveromyces sp. for ethanol production," Bioresource Technology 179(1), 331-338. DOI: 10.1016/j.biortech.2014.11.116

Neves, P. V., Pitarelo, A. P., and Ramos, L. P. (2016). "Production of cellulosic ethanol from sugarcane bagasse by steam explosion: Effect of extractives content, acid catalysis and different fermentation technologies," Bioresource Technology 208(1), 184-194. DOI: 10.1016/j.biortech.2016.02.085 
Olofsson, K., Bertilsson, M., and Lidén, G. (2008). “A short review on SSF - An interesting process option for ethanol production from lignocellulosic feedstocks," Biotechnology for Biofuels 1(7), 1-14. DOI: 10.1186/1754-6834-1-7

Ortíz-Méndez, O. H., Morales-Martínez, T, K., Rios-González, L. J., Rodríguez-de la Garza, J. A., Quintero, J., and Aroca, G. (2017). "Bioethanol production from Agave lechuguilla biomass pretreated by autohydrolysis," Revista Mexicana de Ingeniería Química 16(2), 467-476.

Pando-Moreno, M., Pulido, R., Castillo, D., Jurado, E., and Jiménez, J. (2008). "Estimating fiber for lechuguilla (Agave lechuguilla Torr., Agavaceae), a traditional non-timber forest product in Mexico," Forest Ecology and Management 255(11), 3686-3690. DOI: 10.1016/j.foreco.2008.02.053

Paulova, L., Patakova, P., Branska, B., Rychtera, M., and Melzoch, K. (2015). "Lignocellulosic ethanol: Technology design and its impact on process efficiency," Biotechnology Advances 33(6), 1091-1107. DOI: 10.1016/j.biotechadv.2014.12.002

Paulová, L., Patáková, P., Rychtera, M., and Melzoch, K. (2014). "High solid fed-batch SSF with delayed inoculation for improved production of bioethanol from wheat straw," Fuel 122(1), 294-300. DOI: 10.1016/j.fuel.2014.01.020

Pérez-Pimienta, J. A., Vargas-Tha, A., López-Ortega, K. M., Medina-López, Y. N., Mendoza-Pérez, J. A., Avila, S., Singh, S., Simmons, B. A., Loaces, I., and Martinez, A. (2017). "Sequential enzymatic saccharification and fermentation of ionic liquid and organosolv pretreated agave bagasse for ethanol production," Bioresource Technology 225(1), 191-198. DOI: 10.1016/j.biortech.2016.11.064

Rios-González, L. J., Morales-Martínez, T. K., Rodríguez-Flores, M. F., Rodríguez-De la Garza, J. A., Castillo-Quiroz, D., Castro-Montoya, A. J., and Martinez, A. (2017). "Autohydrolysis pretreatment assessment in ethanol production from agave bagasse," Bioresource Technology 242(1), 184-190. DOI: 10.1016/j.biortech.2017.03.039.

Sant'Ana da Silva, A., de Souza, M. F., Ballesteros, I., Manzanares, P., Ballesteros, M., and Bon, E. P. S. (2016). "High-solids content enzymatic hydrolysis of hydrothermally pretreated sugarcane bagasse using a laboratory-made enzyme blend and commercial preparations," Process Biochemistry 51(10), 1561-1567. DOI: 10.1016/j.procbio.2016.07.018

Saucedo-Luna, J., Castro-Montoya, A. J., Martinez-Pacheco, M. M., Sosa-Aguirre, C. R., and Campos-Garcia, J. (2011). "Efficient chemical and enzymatic saccharification of the lignocellulosic residue from Agave tequilana bagasse to produce ethanol by Pichia caribbica," Journal of Industrial Microbiology \& Biotechnology 38(6), 725 732. DOI: 10.1007/s10295-010-0853-z

Sluiter, A., Hames, B., Ruiz, R., Scarlata, C., Sluiter, J., and Templeton, D. (2008). Determination of Ash in Biomass (NREL/TP-510-42622), National Renewable Energy Laboratory, Golden, CO, USA.

Sluiter, A., Ruiz, R., Scarlata, C., Sluiter, J., and Templeton, D. (2005). Determination of Extractives in Biomass (NREL/TP-510-42619), National Renewable Energy Laboratory, Golden, CO, USA.

Triwahyuni, E., Muryanto, Sudiyani, Y., and Abimanyu, H. (2015). "The effect of substrate loading on simultaneous saccharification and fermentation process for bioethanol production from oil palm empty fruit bunches," Energy Procedia 68(1), 138-146. DOI: 10.1016/j.egypro.2015.03.242

Wang, L., Luo, Z., and Shahbazi, A. (2013). "Optimization of simultaneous saccharification and fermentation for the production of ethanol from sweet sorghum 
(Sorghum bicolor) bagasse using response surface methodology," Industrial Crops and Products 42(1), 280-291. DOI: 10.1016/j.indcrop.2012.06.005

Wang, W., Zhuang, X. S., Yuan, Z. H., Yu, Q., Qi, W., and Wang, Q. (2012). “High consistency enzymatic saccharification of sweet sorghum bagasse pretreated with liquid hot water," Bioresource Technology 108(1), 252-257. DOI: 10.1016/j.biortech.2011.12.092

Xue, Y., Jameel, H., Phillips, R., and Chang, H. M. (2012). "Split addition of enzymes in enzymatic hydrolysis at high solids concentration to increase sugar concentration for bioethanol production," Journal of Industrial and Engineering Chemistry 18(2), 707714. DOI: 10.1016/j.jiec.2011.11.132

Zhuang, X., Wang, W., Yu, Q., Qi, W., Wang, Q., Tan, X., Zhou, G., and Yuan, Z. (2016). "Liquid hot water pretreatment of lignocellulosic biomass for bioethanol production accompanying with high valuable products," Bioresource Technology 199(1), 68-75. DOI: 10.1016/j.biortech.2015.08.051

Article submitted: July 13, 2017; Peer review completed: September 10, 2017; Revised version received and accepted: September 11, 2017; Published: September 15, 2017. DOI: $10.15376 /$ biores. 12.4.8093-8015 